Submission ID: 43721

\title{
Middle Miocene Seismostratigraphic Complex (SSC) in Pannonian Basin
}

T.V. Olneva* (Gazpromneft NTC), E.A. Zhukovskaya (Gazpromneft NTC)

\section{SUMMARY}

These studies of Middle Miocene seismostratigraphic complex (SSC) in Pannonian basin are a logical continuation of the work presented at the conference "Geomodel-2016". A detailed analysis of seismostratigraphic complex allows to open a new level of the target horizons interpretation. 


\section{Сейсмостратиграфический комплекс среднемиоценовых отложений Паннонского бассейна}

Т.В. Ольнева*, Е.А. Жуковская (ООО «Газпромнефть НТЦ»)

\section{Введение}

Данные исследования являются логическим продолжением работ, представленных на конференции «Геомодель» в 2016 году. Предыдущая тема затрагивала отложения нижнемиоценового возраста, настоящая посвящена сейсмостратиграфическому комплексу (ССК) среднемиоценовых отложений /1/.

\section{История геологического развития региона}

Паннонский бассейн локализовался в пределах региона существования моря Паратетис, большинство исследователей относят это событие к раннему миоцену. Полная изоляция Паннонского бассейна датируется уже концом сарматского времени, 11.6 - 11.3 млн. лет назад и предположительно связана с началом конвергенции плит, выраженной в субдукции плиты Апулии под Динариды в Штирийскую фазу Альпийского орогенеза.

В соответствии со стратиграфической схемой среднемиоценовые отложения в районе Центрального Паратетиса подразделяются на баденский и сарматский ярусы, частично к ним относятся низы паннонского яруса. В Восточном Паратетисе баденским отложениям соответствует тархан, чокрак, караган и конка; сарматским и паннонским - сармат $/ 3 /$.

Отложения среднего миоцена изучаемого региона формировались в синрифтовую фазу развития бассейна. Осадконакопление происходило в условиях разобщенных бассейнов, сообщение между которыми периодически восстанавливалось. Начало бадена ознаменовалось крупной трансгрессией, которая привела к открытию коридора сообщения с Мировым океаном через Словению и север Хорватии (рис.1). В баденское время специалисты выделяют несколько циклов третьего и четвертого порядков, однако корреляция с глобальными изменениями уровня моря не прозрачна, приоритет влияния на выделенные циклы во многом у региональной тектоники (рис.2) /4/. Отложения баденского возраста представлены как кластическими породами, так и карбонатными, отмечается широкое присутствие вулканогенного материала.

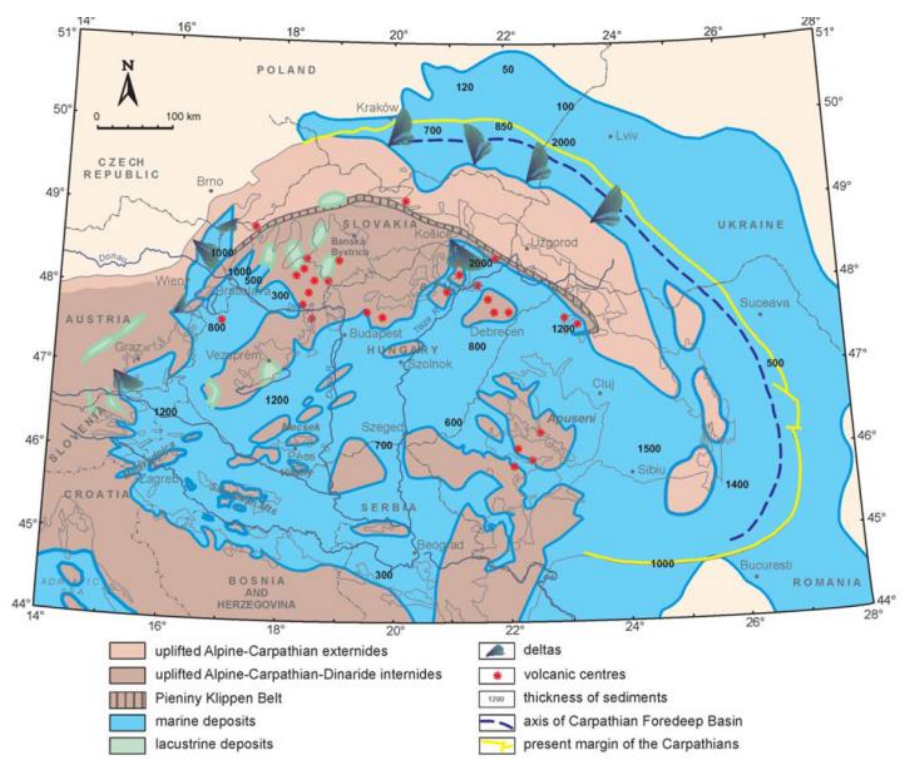

Рисунок 1. Палеогеографическая реконструкция Центрального Паратетиса на время позднего Бадена (13.6 - 12.7 млн.лет) /4/ 


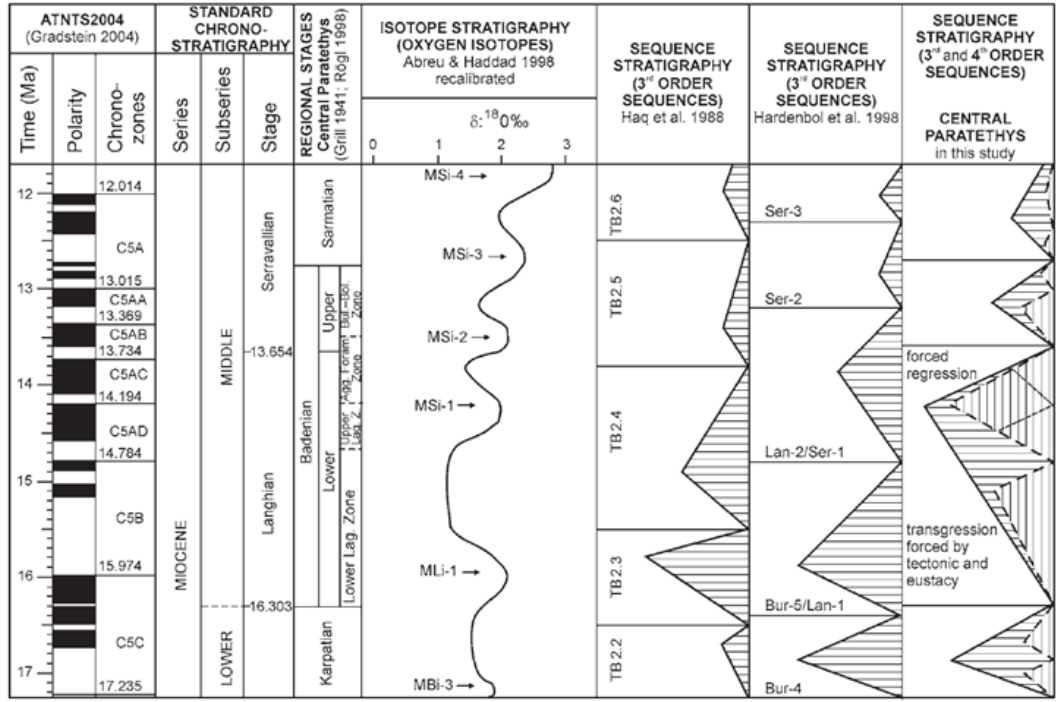

Рисунок 3 Цикль третьего и четвертого порядка относительного изменения уровня моря в Центральном Паратетисе /4/.

Сарматские отложения, также накапливались преимущественно в мелководно-морских условиях. Геологические события, происходившие в сарматское время, подробно описаны в работе Р.Йовановича (2010) описаны три фазы: фаза площадного карбонатного осадконакопления в раннем сармате и последующие две фазы активных тектонических движений в раннем и позднем сармате, которые привели к формированию расчлененного рельефа, впоследствии эродированного, чем и объясняется локальное распространение сарматских отложений в палеопогруженных участках донеогенового основания.

Отложения среднемиоценового комплекса представляют базальные образования, возникшие на трансгрессивном этапе развития локально, в депрессиях, на отложения нижнемиоценового возраста. В зависимости от этого, по-разному определяется нижняя граница ССК. Отражение от поверхности донеогенового основания в регионе, как правило, является комплексным откликом, неустойчиво по латерали, во многом зависит как от состава пород фундамента, так и от строения перекрывающей его толщи. С этим моментом связаны проблемы интерпретации отражающих горизонтов, характеризующих распределение отложений нижнего и среднего миоцена, перекрывающих донеогеновое основание. В пределах участков, характеризующихся полным разрезом отложений среднемиоценового возраста, на сейсмических разрезах можно выделить интервалы с «морским» заполнением и «континентальным». В первом случае сейсмическое изображение более контрастно и состоит из достаточно протяженных ярких отражений; во втором случае выглядит более приглушенно и хаотично. Причина кроется в близости состава обломочной части баденских отложений и пород фундамента. Большинство отражений носит интерференционный характер. Верхней границей комплекса, является акустическая граница на контакте с отложениями паннонского возраста.

Основные сложности в интерпретации ССК создает локальный характер его распространения, наличие разломов, интерференция с отражением от поверхности донеогенового основания, неопределенности в идентификации стратиграфических разбивок, дефицит кернового материала для исследований (до последнего времени). В настоящее время пробел в описании кернового материала заполняется. Современный уровень исследований предполагают комплексный подход к анализу кернового материала, результатом которого является седиментационная модель.

\section{Пример}

В районе исследования скв. X северный склон выступа фундамента сложен неизмененными гипергенными процессами магматическими породами, в кровле которых залегают трещиноватые и брекчированные слабоизмененные интрузивы среднего состава, перекрытые элювиальными отложениями, представленными крупными (размером до 1,2 м) неокатанными и полуокатанными глыбами и валунами слабоизмененных пород фундамента - «базальная 
конглобрекчия». Пространство между глыбами заполнено конгломератом. Постепенно вверх по разрезу уменьшается максимальный размер обломков и возрастает окатанность. Такие осадки могут быть отнесены к проксимальной (привершинной) части пролювиального конуса выноса с предполагаемым первичным наклоном до 5-10. Эта зона конуса слагается самыми грубообломочными отложениями, относящимися к потоковой фации.

Выше залегает преимущественно гравелитовая толща, превосходящая конгломераты по мощности в 2,5 раза. Она имеет ритмичное строение, существенное утонение обломков вверх по разрезу и сокращение мощности прослоев конгломератов с сохранением объема ритма. Такие признаки указывают на накопление осадков в привершинной (проксимальной) и средней (медиальной) части пролювиальных/аллювиальных конусов выноса. Отмеченная тенденция уменьшения максимального размера и увеличения степени окатанности обломков при удалении от фундамента вверх по разрезу может быть связана с постепенным затуханием интенсивности стока временных водотоков. Необходимое условие для возникновения пролювиального конуса выноса - обильное поступление осадочного материала может быть инициировано тектонической активизацией или перестройкой климатического режима.

Генетические признаки обломочных отложений, мощности единичных сходов, отсутствие четкой дифференциации осадка и реликтов палеопочв на поверхности единичных сходов свидетельствуют о незначительных масштабах конуса выноса - протяженностью несколько сотен метров. Стабилизации воздымания территории в период формирования пролювиального конуса не наблюдается вплоть до начала резкой трансгрессии, диагностируемой по появлению литотамний и других признаков мористости в гравелитах.

Падение склона по сейсмическим данным имеет предположительно северное, северо-западное направление.

Одновременно с формированием конуса выноса на северном склоне, с противоположной более погруженной на тот момент части рельефа (скв. Ү), частично заполненной осадками мутьевых (селевых?) потоков в раннем миоцене и превратившейся в водоем (подпрудное озеро(?)- залив) происходило внедрение пролювиального (алювиального) конуса, сложенного грубообломочными осадками. Для этих конгломератов характерно ритмичное строение с максимальным размером обломков 8-20 cм, мощность ритмов от 0,5 до 1,5м. Начало трансгрессии, в отличие от северного склона, фиксируется по появлению в разрезе среднемелкозернистых песчаников с морской фауной и типичной биотурбацией сколитовой ихнофации (ихнороды Ophiomorpha, Arenicolites $u$ дp.). Резкое наступление моря привело к повсеместному затоплению территории и отложению литотамниевых известняков, сменяющихся выше по разрезу микритовыми известняками.

Таблица №̄1. Результаты генетической интерпретации керна.

\begin{tabular}{|c|c|c|c|c|}
\hline \multicolumn{3}{|c|}{ Скважина X - «Север» } & \multicolumn{2}{|c|}{ Скважина Y - «Юг» } \\
\hline Фация & $\begin{array}{c}\text { Литологическая } \\
\text { характеристика }\end{array}$ & Фото керна & $\begin{array}{l}\text { Литологическая } \\
\text { характеристика }\end{array}$ & Фото керна \\
\hline $\begin{array}{l}\text { Мелководно- } \\
\text { морские } \\
\text { карбонатные } \\
\text { (внутренний } \\
\text { шельф) }\end{array}$ & $\begin{array}{c}\text { Известняки } \\
\text { литотамниевые }\end{array}$ & & $\begin{array}{c}\text { Известняки } \\
\text { литотамниевые }\end{array}$ & \\
\hline $\begin{array}{l}\text { Мелководно- } \\
\text { морские } \\
\text { терригенные } \\
\text { (внутренний } \\
\text { шельф) }\end{array}$ & $\begin{array}{c}\text { Гравелиты } \\
\text { литотамнивые }\end{array}$ & & $\begin{array}{c}\text { Песчаники } \\
\text { мелкозернистые с } \\
\text { морской } \\
\text { биотурбацией }\end{array}$ & \\
\hline $\begin{array}{c}\text { Конус выноса } \\
\text { пролювиальны } \\
\text { й средняя } \\
\text { часть } \\
\text { (медиальная) }\end{array}$ & $\begin{array}{c}\text { Гравелиты с } \\
\text { песчаным матриксом } \\
\text { ритмичные за счет } \\
\text { изменения } \\
\text { зернистости }\end{array}$ & & & \\
\hline
\end{tabular}




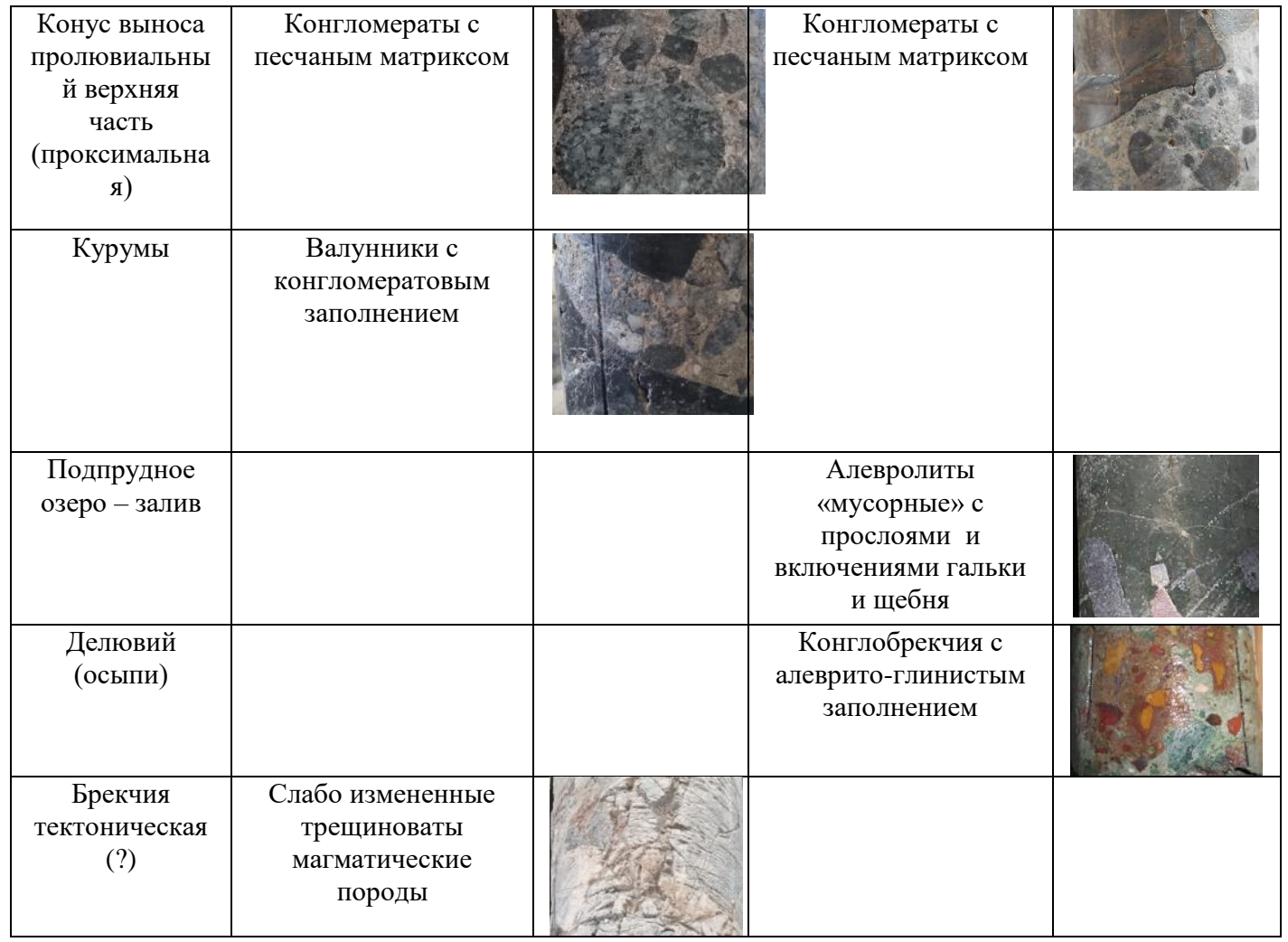

\section{Выводы}

Детальный анализ сейсмостратиграфического комплекса в целом, позволяет выйти на новый уровень интерпретации целевых горизонтов. Понимание взаимосвязи особенностей сейсмического изображения с процессами, которые сформировали изучаемые отложения помогает углубленной геологической интерпретации сейсмических данных.

Комплексные разномасштабные подходы анализа геолого-геофизических данных на разрабатываемых месторождениях позволяют обновлять концептуальные модели и разрабатывать подходы к поиску новых месторождений-спутников.

\section{Библиография}

1. Ольнева Т. Сейсмостратиграфический комплекс нижнемиоценовых отложений Паннонского бассейна. Тезисы к конференции «Геомодель 2016». 2016.

2. Басов И.А. Океанская и климатическая эволюция в миоцене. Природа. N 5.- 1999.

3. Попов С.В., Ахметьев М.А., Лопатин А.В. и др. Палеогеография и биогеография бассейнов Паратетиса. Часть 1. Поздний эоцен - ранний миоцен. М.: Научный мир. 2009. - 200 с.

4. Kovac M. Badenian evolution of the Central Paratethys Sea: paleogeography, climat and eustatic sea-level changes. Geologica Carpathica, December 2007. 58.6. P. 579-606.

\section{References}

1. Olneva T. Seismostratigraphic complex of lower Miocene sediments of the Pannonian basin. Abstracts for the conference "Geomodel 2016". 2016.

2. Basov I.A. Oceanic and climatic evolution in the Miocene. Nature. N 5. 1999.

3. Popov S. V., Akhmetev M. A., Lopatin A.V. and others. Paleogeography and biogeography of Paratethys's basins. Part 1. Late Eocene - early Miocene. M.: Scientific world. 2009.200 p.

4. Kovac M. Badenian evolution of the Central Paratethys Sea: paleogeography, climat and eustatic sea-level changes. Geologica Carpathica, December 2007. 58.6. P. 579-606. 